\title{
Innovative Higher Education Teaching and Learning Techniques: Implemen- tation Trends and Assessment Approaches
}

\section{Piyush Taneja}

Ms. Elnaz Safapour, University of Texas at Arlington

Dr. Sharareh Kermanshachi, University of Texas at Arlington

Dr. Sharareh (Sherri) Kermanshachi is an Assistant Professor in the Department of Civil Engineering at the University of Texas at Arlington. Dr. Kermanshachi has received her Ph.D. degree in Civil Engineering from Texas A\&M University. She also holds a Master's degree in Civil Engineering from Mississippi State University and an MBA from Eastern Mediterranean University in Famagusta, Cyprus. Her areas of expertise are performance-based modeling, project delivery methods, communication networks, and uncertainty and risk analysis in design and construction of transportation projects. She also has industrial experience as a project manager in multiple building construction projects. Dr. Kermanshachi has conducted several research projects which were awarded by Texas Department of Transportation (TxDOT), National Cooperative Highway Research Program (NCHRP) and Construction Industry Institute (CII). Dr. Kermanshachi has received several prestigious national and regional awards, including the American Society of Civil Engineers (ASCE) Professional Service Award, ASCE Excellence in Education (ExCEEd) Fellowship, Aggies Commit to Professional Student Educational Experiences, Graduate Teaching Lecturer Fellowship, and Climate Award. She was also the only academic recipient of the Texas and Louisiana Engineering News Record (ENR) Top Young Professional Award in 2017. Dr. Kermanshachi is currently directing a very vibrant construction engineering and education research group and advising several Ph.D. and Master's students 


\section{Innovative Higher Education Teaching and Learning Techniques: Implementation Trends and Assessment Approaches}

\section{Mr. Piyush Taneja, University of Texas at Arlington}

Graduate Student, Department of Civil Engineering, University of Texas at Arlington, 425 Nedderman Hall, 416 Yates Street, Arlington, TX 76019. E-mail:

piyush.taneja@mavs.uta.edu

\section{Ms. Elnaz Safapour, University of Texas at Arlington}

$\mathrm{PhD}$ Student, Department of Civil Engineering, University of Texas at Arlington, 425 Nedderman Hall, 416 Yates Street, Arlington, TX 76019. E-mail:

elnaz.safapour@mavs.uta.edu

\section{Dr. Sharareh Kermanshachi, University of Texas at Arlington}

(Corresponding Author) Assistant Professor, Department of Civil Engineering, University of Texas at Arlington, 438 Nedderman Hall, 416 Yates Street, Box 19308, Arlington, TX 76019, USA. E-mail: sharareh.kermanshachi@uta.edu 


\title{
Innovative Higher Education Teaching and Learning Techniques: Implementation Trends and Assessment Approaches
}

\begin{abstract}
Education plays an important and critical role globally in developing a skilled workforce. For many decades, the use of textbooks has been the traditional method of instruction; however, the emergence and implementation of teaching effectiveness assessment techniques has revealed that most students do not absorb the course content up to the expected level. As a result, many researchers have focused on advancing and improving the existing learning methods, as well as introducing and experimenting with new teaching styles. Unfortunately, researchers have been unable to agree on the effectiveness of the new teaching methods; consequently, they require further investigation. To address this problem, five innovative and effective teaching methods across all the engineering disciplines were selected (flipped classroom, gamification, design thinking/ case study, self-learning, and social media), and indepth content analyses of them were conducted. The advantages associated with each of the targeted new teaching method were explored, and data pertaining to teaching methods was identified and assessed. The results revealed that between the years of 2000 and 2017, the self-learning method and Social Media were researched and written about in journal articles significantly more often than other teaching methods. Most of the researchers distributed surveys/questionnaires to collect the data needed for the assessment of the adopted teaching techniques. It was concluded that adoption of Self-learning teaching method will improve research skills and thinking ability of learners. In addition, utilization of Social Media will increase effective communication among learners. The outcomes of this study have the potential to substantially help instructors, lecturers, and professors adopt the most effective teaching styles, based on their course learning objectives.
\end{abstract}

\section{Introduction}

Education is an important component of every society which could significantly contribute to a country's economic growth ${ }^{1}$. In an era where technology enhancements and innovations are in their prime, there are many opportunities for innovative learning and teaching methodologies. Traditional teaching methods were primarily based on a teacher explaining a topic of a textbook; students were not active participants in the class ${ }^{2}$. New teaching methods, however, encourage the students to take an active role in the class to awaken their curiosity and creativity. McCarthy and Anderson ${ }^{3}$ (2000) conducted research to study, analyse, and compare the outcomes of students taught by traditional methods with those of students taught by the active learning methodology. The results of quizzes demonstrated that the students involved in active learning achieved higher scores than those who were taught by the traditional way. More studies are being conducted and several new methods are being introduced and applied experimentally to improve student productivity and output. In this respect, several methods have been introduced and utilized to measure the effectiveness of implemented educational methods.

Throughout the past two-decades, numerous researchers have attempted to identify a unique teaching method that will facilitate effective learning for all students. However, most researchers agree that there is no one teaching method which fits all different types of 
students across all ages and races ${ }^{4}$. Also, several researchers utilized various methods to assess the effectives of various teaching methods. ${ }^{5}$

The researchers have introduced five new teaching methods: flipped classroom, gamification, design thinking, self-learning, and social media. The objective of this study was to conduct a comprehensive review of the five stated new teaching methods based on the existing literatures between 2000 and 2017 and perform in-depth analyses of their approaches. Three steps were taken to achieve these goals: (1) the distribution of the utilized teaching methods from 2000 to 2017 was identified, and (2) the implemented effectiveness assessment methods for the five identified teaching methods were determined for the past 17 years, and (3) identify the learning objectives associated with each stated teaching method. The results of this study will significantly address the potential challenges associated with learners and help instructors and professors select the most effective teaching methods based on the learning objectives for their courses.

\section{Research Methodology}

To fulfil the objectives of this study, more than 2,000 peer-reviewed journal articles, conference papers, dissertations, and research reports that focused on the five types of new teaching methods (flipped classroom, gamification, design thinking, social media and selflearning) were identified and collected. The identified academic sources were published from 2000 to 2017. As the number of identified related journals was adequate and their publication is subject to a more rigorous review process than the other sources, the authors decided to solely focus on them. Among the collected journal articles, the authors conducted in-depth analyses for more than 150 journal papers and conference proceedings.

As shown in Figure 1, the journal articles were extracted primarily from the Google Scholar search engine. All of them were thoroughly reviewed, and essential information was taken from each of them, including the name of journal, the year of the study, and the type of teaching methodology. Some data analyses were performed after completing the data base. In the final step, the results were interpreted, and a conclusion was obtained.

Based on the U.S. Department of Education's 2005 "Condition of Education" report", enrolment in colleges and universities will increase at a constant rate. Therefore, it is essential for instructors to identify an efficient method of instruction for engineering students, according to the course learning objectives. Most studies measure the effectiveness of a teaching method by the output of the students, and teachers are faced with deciding which method is most efficient for their class. The following comprehensive literature review of published journal articles for the following five non-traditional teaching methods attempts to provide data that will assist in making this decision. 


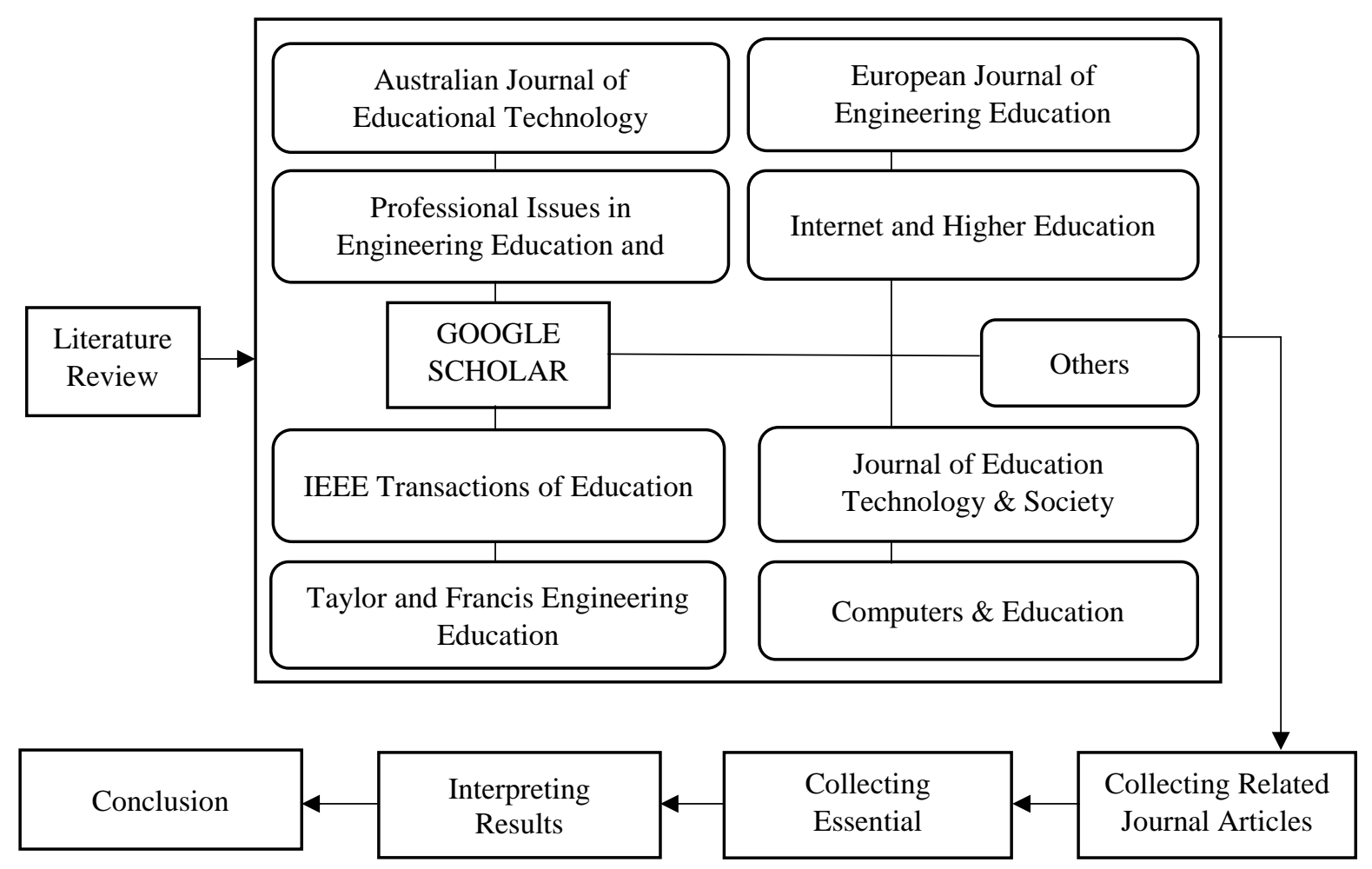

Fig 1. Research methodology.

\section{Flipped Classroom}

Lage et al. ${ }^{7}$ (2000) explained that "Inverting the classroom means that events that have traditionally taken place inside the classroom now take place outside the classroom and vice versa." What really happens in the flipped classroom teaching method is that the theoretical knowledge from lectures and course materials are posted online for the students to study at home ${ }^{8}$.

M.K. Kim et al. ${ }^{9}$ (2014) identified nine design principles for the flipped classroom, three of which were adopted and validated by Brame $^{10}(2010)$ : provide an opportunity for students to gain first exposure prior to class; offer incentives to students to prepare for class; develop a mechanism to assess student levels of understanding. The other six principles were to provide: clear connections between in-class and out-of-class activities; clearly defined and well-structured guidance; enough time for students to carry out the assignments; facilitation for building a learning community; prompt/adaptive feedback on individual or group works; and familiar and easy-to-access technologies.

Anderson et al. ${ }^{11}$ (2017) observed significant enhancement of students' short-term performance within six weeks to six months of being taught by the flipped classroom method. In the study of Koo et al. ${ }^{12}$ (2016), pre-test and post-test results were utilized to evaluate the effectiveness of the method, and it was concluded that there was significant improvement in student performance and satisfaction, although a few students indicated a problem with the time requirement. Moravec et al. ${ }^{13}$ (2010) utilized the flipped class methodology and observed a $21 \%$ increase in student performance. Kostaris et al. ${ }^{14}$ (2017) observed that the flipped classroom teaching method impacts low, medium, and high performing groups. Their research also demonstrated that the lowest performing group benefitted the most from being more engaged and motivated. 
Simpsom and Richards ${ }^{15}$ (2015) explained that there was no statistically significant difference between the performance of students taught by the traditional method and those taught by the flipped class methods. However, the majority of students indicated that the new course design allowed them greater flexibility and the ability to control the pace of learning, making them feel being more responsible for their own learning. They also indicated that it provided a supportive, active learning environment which enhanced interaction and engagement. Dochy et al. ${ }^{16}$ (2003) and Gibels et al. ${ }^{17}$ (2005) tested this teaching method, and concluded that implementation of the flipped classroom or problem-based learning positively affects students' abilities to obtain needed skills and gain advanced knowledge.

\section{Gamification}

Students' interests in gaming and technology are at an all-time high and make this method of teaching very popular. It is effective, in part, because students learn without having to engage in the traditional learning process - they practically learn without even realizing it! Competition and scoring motivate and involve the students, and although scoring doesn't affect the student learning, it motivates them to try hard ${ }^{18}$. Huotari ${ }^{19}$ (2013) and Hamari ${ }^{20}$ (2012) defined gamification as a process of enhancing services with motivational affordances to invoke gameplay experiences and further behavioral outcomes. The main motivation is to improve the involvement of individuals and increase their interest, engagement, and efficiency ${ }^{21}$. People who enjoy game-based learning only exhibit an increase in satisfaction, enjoyment, and relevance to the job ${ }^{22}$. According to the study conducted by Michele D. $\operatorname{Dickey}^{23}$ (2007), there are elements within the design of multiple online role-playing games which foster intrinsic motivation while requiring players to think, plan, and act critically and strategically. Sung and Hwang ${ }^{24}$ (2013) studied learning attitudes, motivation, and selfefficacy and found improvement in all three areas, as well as student confidence, by using collaborative educational computer games with a repertory grid $^{24}$. A course study utilizing the game mechanics of points, badges, and a leaderboard done by postgraduate students showed more involvement in forum discussions, improved quality of group artefacts produced by participants, and increased motivation ${ }^{25}$. Gamification increases motivation for learning which requires less previously acquired knowledge and, as a tool combined with other methodology, increases learning outcomes. It is not, however, fully dependable for learning outcomes ${ }^{26}$.

Baldeon et al. ${ }^{27}$ (2015) used gamification to teach mathematics and increase students' involvement by designing a game that required using fractions and answering questions to advance to another stage. Although the students scored better in practical assignments, they performed poorly in written assignments and participated less in classroom activities, irrespective of being more motivated ${ }^{28}$.

\section{Design Thinking (Case Study)}

The main concept of design thinking is that students learn by being exposed to real-life problems or case analyses and using procedures like group interaction and brainstorming, as well as many others, to gain knowledge and enhance their critical thinking ability. Cases are selected for benefitting theoretical outcomes, and the relevant case is selected for a learning outcome. This method is also helpful for postgraduate students who are willing to do a thesis to gain in-depth knowledge ${ }^{29}$. Graduate students can relate to their own experience, and undergraduate students can learn from seniors when using the case study approach ${ }^{30}$. In this 
regard, Wang and Hannafin ${ }^{31}$ (2005) identified characteristics of design-based research and its importance for technology-enhanced learning and meeting future challenges.

Inna Popil ${ }^{32}$ (2011) observed that critical thinking was enhanced when case studies were used as teaching method. Based on his experimental results and an increase in student performance, Mayo $^{33}$ (2004) presented that case-based instruction promotes critical thinking. A study conducted by Tiwari et al. ${ }^{34}$ (2006) concluded that problem-based learning results in a significant improvement in students' critical thinking and active participation in the learning process. Korkmaz ${ }^{35}$ (2012) observed, from research on graduate students being exposed to case-based collaborative-learning methods, that pre-and-post case study assignments, role playing, and class discussions improved key delivery parameters, especially for design integration and team characteristics. The students were more interested, and the results obtained were better than those of the traditional method.

In a research based on a mechanical engineering course conducted by Yadav et al. ${ }^{36}$ (2014), it was found that students' conceptual understanding was significantly higher when they learned from case-based instruction as compared to traditional lectures. Additionally, case studies promoted more engagement and connections to the real world. Students' self evaluations showed that they did not feel that case studies improved their learning; however, researchers later argued that student perceptions are not accurate predictors of actual learning outcomes. According to Chetan et al. ${ }^{37}$ (2008), design thinking results in improved critical and practical thinking, and facilitates higher levels of evaluation and analysis. Essay questions and viva-type questions were asked to determine how much in-depth knowledge had been attained. The authors explained that this method is time-consuming, and students dislike viva questions. Essay writing reveals the students' in-depth knowledge, but it is difficult for the grader to grade. In a research study conducted by Kenneth Gavin ${ }^{38}$ (2011), a lecture was given to students in which three professors presented case studies. The students met weekly to present their work to the person who designed the problem and two other faculy members. An assessment was performed, and about $70 \%$ of the students wanted to include the case study approach in other curriculums, and about $90 \%$ felt that they gained knowledge from this curriculum.

\section{Self-Learning}

Learning for the sake of one's own knowledge by conducting research, reading articles and books, or employing other platforms is termed as self-learning or self-directed learning. Everyone takes advantage of this methodology to some extent, and many well-known personalities, such as Marie Curie ${ }^{39}$ have been studied. Rodney Stwart ${ }^{40}$ (2007) conducted a study in which three factors of self-learning were evaluated: self-management, desire for learning, and self-control. It was concluded that the respondents had a strong desire for learning, and they were expected to complete the undergraduate program and gain work experience, Self-management had the lowest rating, indicating that the students had issues with planning and time management of their studies.

Rothwell and Sensenig ${ }^{41}$ (1999) mentioned some advantages of the self-learning teaching method, such as the opportunity to select one's field of study and studying at your own pace, according to individual schedules. Students have the privilege of assessing their own performance, enabling them to rate themselves, figure out where they went wrong, and take the required steps to rectify their errors ${ }^{42}$. Long and Guglielmino ${ }^{43}$ (2008) termed the learner as a thinker and creator of knowledge rather than as a passive individual who is dependent on others' knowledge. The importance of self-directed learning has been put in three contexts: 
(1) self-directed learning in the workplace, (2) self-directed learning for personal effectiveness and satisfaction, and (3) self-directed learning in formal learning settings. It was observed that with the application of the self-directed learning approach, students learn successfully and enjoy a feeling of satisfaction with both the course and the teaching approach $^{44}$. Brookfield ${ }^{45}$ (2008) provided a critical reflection of self-directed learning, stating its inadequate theoretical base.

\section{Social Media}

Learning and teaching platforms are no longer limited to books and traditional lectures, as different types of social media tools, like blogs, twitter accounts, LinkedIn, etc., are being used by both students and professors. The use of social media platform in the field of education has always been a matter of debate, and there are many positives and negatives to consider. Facebook, wiki, twitter, blogs and other forms of social media are used, and advantages have been observed, such as the students engaging with content; peer learning; promotion of critical thinking; self-directed learning; self-monitoring of the learning progress, provision of a platform from which students can interact with lecturers; and an enjoyable and interactive learning environment ${ }^{46}$. Such an environment, with social aspects connected to studying and student life, equates with enhancing studies and providing a needed tool, especially for students in the early phase of studies in a new university ${ }^{47}$. In another study conducted by Baruah $^{48}$ (2012), the impact of social media as a communication tool was discussed, as was the potential of social media as a tool for technology-enabled connections. It was concluded that Twitter is an easy tool for searching for needed content and learning of the latest innovations and/or news updates ${ }^{49}$.

In a comprehensive research conducted by Alasdair Blair ${ }^{49}$ (2014), 252 undergraduate students in business and management were encouraged to use Twitter for communicating with their tutor and each other during a 12-week course. Their involvement was evaluated, using a survey that considered the amount of Twitter usage and students' attitudes and experiences. The data was analyzed using factor analyses, which revealed a single usage construct and three attitudinal factors. Three findings emerged: a positive correlation was found between the amount of Twitter usage and students' organization of their social lives and sharing information; tweeting related to the course was not related to internal relationships between students and their tutor; and Twitter usage had no impact on class attendance.

In a study of a Facebook group for chemistry, students initially didn't find it helpful for learning. When it was utilized actively for a period of two years, however, their views changed and they found it helpful for learning chemistry ${ }^{50}$. The Facebook group exhibited a higher level of technological self-efficacy, greater willingness to use the Facebook group, and higher learning motivation.According to the students, Facebook has become part of college students' lives and provides a simple, convenient, easy, and user-friendly learning environment ${ }^{51}$.

\section{Results and Discussions}

Distribution of different types of collected data was identified by reviewing all the journal articles identified for this study. As shown in Figure 2, seven types of data collection were employed by authors of reviewed journal articles: exams, quizzes, interviews, case studies, 
surveys/questionnaires, assignments, and instructor reflection. The distribution of surveys/questionnaires and results of exams were ranked first and second, with $44 \%$ and $20 \%$, respectively. Many researchers preferred to use a structured survey to collect information, as it lends itself to collecting data from a large number of respondents, as well as facilitating ease in organizing the collected data.
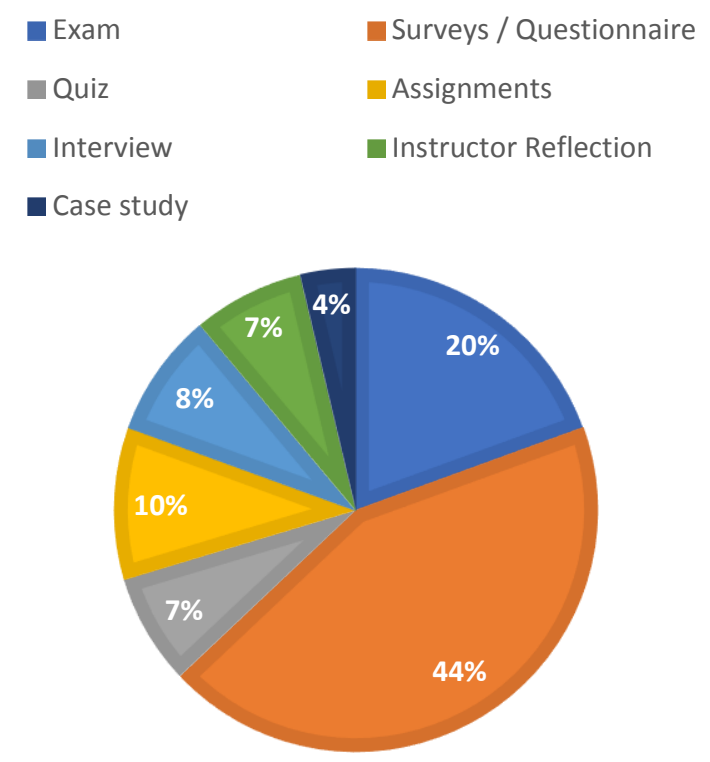

Fig 2. Distribution of data collection types.

The percentage of each new teaching method employed was identified through reviewing the journal articles between 2000 and 2017. As shown in Figure 3, the results revealed that the percentages of self-learning and case study teaching methods were roughly $50 \%$ and $30 \%$, respectively. The results highlighted that the self-learning method has become popular worldwide since the availability of free information on the internet. In addition, utilization of the case study method leads to an improvement in efficient communication skills and fosters cooperation among learners.

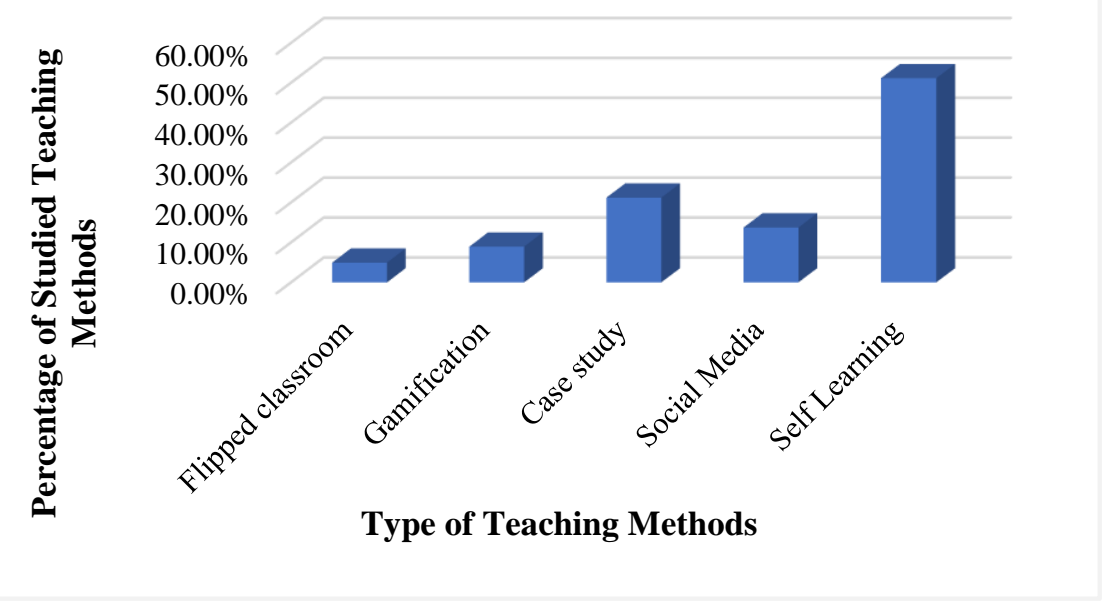

Fig 3. Percentages of studied new teaching methods employed.

The trends of new teaching methods reviewed in published journal articles between 2000 and 2017 were identified and analysed, as illustrated in Figure 4. It should be noted that a few 
papers in our database were published before the year 2000; they were not included in the trend analyses of the present study. As is shown in Figure 3, research of the self-learning method has been very popular during the last seventeen years. Although a few studies were conducted from 2000 to 2004 in the area of utilizing social media as a teaching method, studies focusing on assessing the implementation of this method significantly increased after 2004. It was concluded that self-learning and social media were the two teaching methods which were the focus of most studies conducted between years 2000 and 2017.

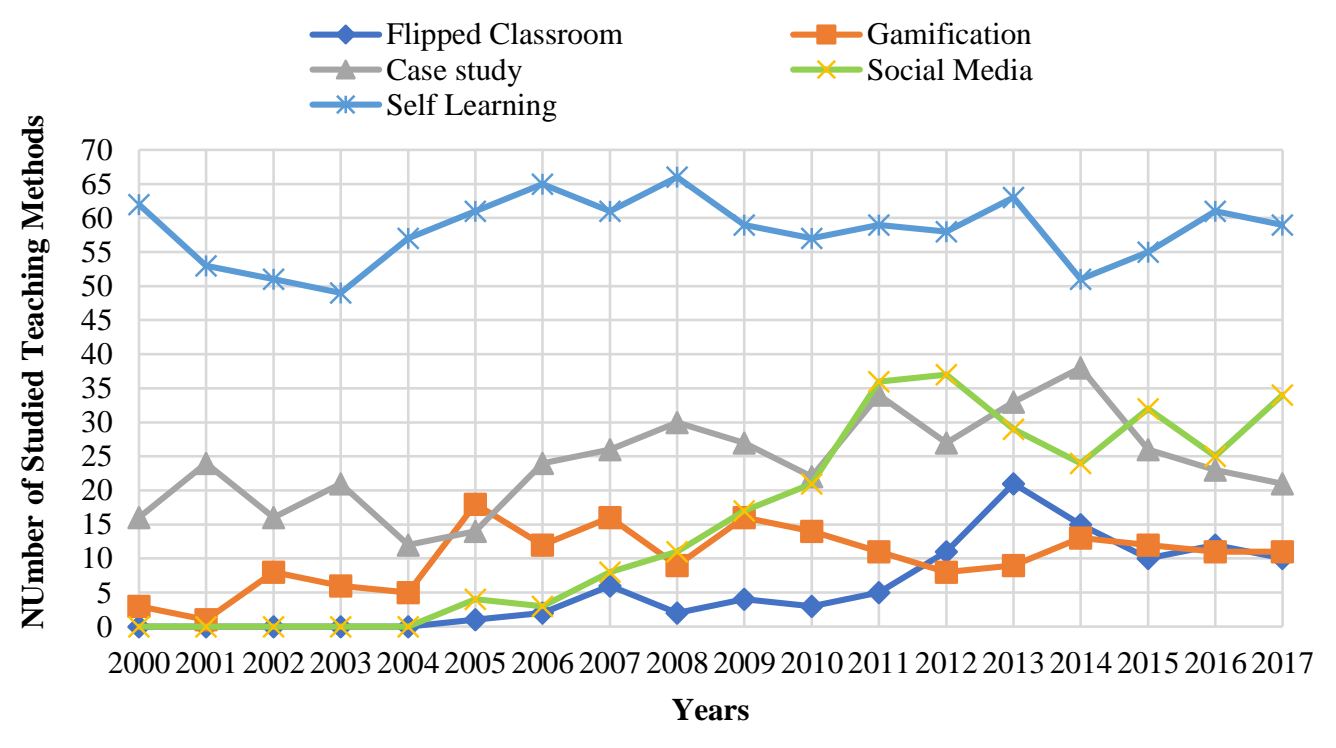

Fig 4. Trend of new teaching methods over years $2000-2017$.

The learning objectives associated with each teaching method are listed in Table 1. As indicated in Table 1, implementation of Flipped Classroom teaching method drives learners to use many techniques such as discussion and class exercise during the class time. Therefore, this method would improve students' participation in learning procedures. In addition, when Flipped classroom method is adopted, the learners were supported by instructors in class exercises and assignments and consequently, the effective communication between learners and instructor is increased.

As illustrated in Table 1, utilization of Gamification is an effective method for learning vocabulary. As this method implies the game elements such as points, reward is a key aspect of this teaching style. Therefore, adoption of Gamification would increase motivation of learners. As indicated in this table, utilization of Design Thinking teaching method could enhance creativity of learners. As a consequence, increasing creativity leads to improvement of analytical thinking, critical thinking, and solving ability of learners. Moreover, implementation of this teaching method would enhance problem solving skill of learners as it is inherently solution-based approach.

Adoption of Self-learning teaching method causes more involvement of students in conducting a self-evaluation of their current situation and study habits. Therefore, this method would help to improve research skills and thinking ability of learners. In addition, as indicated in Table 1, utilization of this teaching method is useful for learners who suffer from Autism Spectrum Disorders (ASD). Implementation of Social Media teaching method will 
increase effective communication skills among learners by performing team-building exercises. Team-building exercises could help learners sharpen both oral and written communication skills. Furthermore, adoption of this method is very beneficial for developing networking that is necessary for seeking a job and employment.

Table 1. Learning objectives associated with teaching methods.

\begin{tabular}{|c|c|c|}
\hline $\begin{array}{l}\text { Teaching } \\
\text { Methods }\end{array}$ & Learning Objectives & Research Studies \\
\hline $\begin{array}{c}\text { Flipped } \\
\text { Classroom }\end{array}$ & $\begin{array}{l}\text { - increase communication between students and instructor } \\
\text { - improve student participation in learning procedure }\end{array}$ & $\begin{array}{l}\text { Bergman }(2013)^{52} \\
\text { Kostaris }(2017)^{53}\end{array}$ \\
\hline Gamification & $\begin{array}{l}\text { - develop interpersonal skills } \\
\text { - increase motivation } \\
\text { - improve analytical thinking } \\
\text { - effective for learning vocabulary }\end{array}$ & $\begin{array}{l}\text { Phillips }(2015)^{54} \\
\text { Sung }(2013)^{55} \\
\text { Kayali }(2013)^{56} \\
\text { Walsh }(2014)^{57}\end{array}$ \\
\hline $\begin{array}{c}\text { Design } \\
\text { Thinking } \\
\text { (Case Study) }\end{array}$ & $\begin{array}{l}\text { - influential way to portray something } \\
\text { - improve problem solving ability } \\
\text { - improve ability to apply theoretical knowledge in real life situation } \\
\text { - improve analytical and critical thinking }\end{array}$ & $\begin{array}{l}\text { Linder }(1990)^{58} \\
\text { Henry }(2005)^{59} \\
\text { Ching }(2014)^{60} \\
\text { Bonney }(2015)^{61} \\
\text { Birgili }(2015)^{62}\end{array}$ \\
\hline Self-Learning & $\begin{array}{l}\text { - improve thinking ability } \\
\text { - improve research skills } \\
\text { - improve social skills } \\
\text { - improve proficiency to use technological applications } \\
\text { - useful for Autism Spectrum Disorders (ASD) students }\end{array}$ & $\begin{array}{l}\text { Kreber }(1998)^{63} \\
\text { Smith }(2001)^{64} \\
\text { Douglass }(2014)^{65} \\
\text { Park }(2009)^{66} \\
\text { Mechling }(2009)^{67}\end{array}$ \\
\hline Social Media & $\begin{array}{l}\text { - enhance engagement of students in learning procedure } \\
\text { - improve communication skill } \\
\text { - help in networking and preparing for employment } \\
\text { - help to stay updated with new information and technologies }\end{array}$ & $\begin{array}{l}\text { Junco }(2010)^{68} \\
\text { Junco }(2010)^{68} \\
\text { Hunga }(2010)^{69} \\
\text { Kiyunja }(2014)^{70} \\
\text { Mao }(2014)^{71}\end{array}$ \\
\hline
\end{tabular}

\section{Conclusions}

Many researchers are studying teaching and learning outcomes in an effort to maximize the outcomes while benefitting students. From journal articles between 2000 and 2017, this research selected five new and effective teaching methods (Flipped Classroom, Gamification, Design Thinking/Case Study, Self-Learning, and Social Media) that can be used across all engineering disciplines. The distribution of data collection types was identified and correlated to the five teaching methods. The results demonstrated that many studies have been conducted about self-learning teaching methods, as free data is accessible and available globally for everyone. Furthermore, it was concluded that many researchers prefer using surveys/questionnaires as a means of collecting data from a large number of respondents. The results demonstrated that adoption of Self-learning teaching method will improve research skills and thinking ability of learners. This study also concluded that utilization of Social Media teaching method will increase effective communication among learners. Selection of the most effective and appropriate teaching technique requires a lot of knowledge and involves a lot of factors. This study will help faculty members select the appropriate teaching methodology according to the course learning objectives to meet the students' needs and concerns, benefitting both students and teachers. 


\section{References}

1. Kermanshachi, S. and Safapour, E. (2017), “Assessing Students' Higher Education Performance in Minority and Non-Minority Serving Universities," Proceedings of Frontiers in Education (FIE), IEEE, Indianapolis, Indiana, October 3-6, 2017.

2. Jahan Nipa, T., and Kermanshachi, S. (2018), "Analysis and Assessment of Graduate Students' Perception and Academic Performance Using Open Educational Resource (OER) Course Materials", Proceedings of ASEE Annual Conference and Exposition, Salt Lake City, UT, June 24-27, 2018.

3. McCarthy, J. P. and Anderson, L. Active Learning Techniques Versus traditional teaching styles: Two experiments from history and Political Science. Innovative higher education, 24 (4), 2000.

4. Kermanshachi, S., Anderson, S., Molenaar, K., and Schexnayder, C. (2018), "Effectiveness Assessment of Transportation Cost Estimation and Cost Management Workforce Educational Trainings for Complex Projects", Proceedings of ASCE International Conference on Transportation \& Development, Pittsburgh, PA, July 15-18, 2018.

5. Kermanshachi, S. and Sadatsafavi, H., (2018), "Predictive Modelling of U.S. Transportation Workforce Diversity Trends: A Study of Human Capital Recruitment and Retention in Complex Environments", Proceedings of ASCE International Conference on Transportation \& Development, Pittsburgh, PA, July 15-18, 2018.

6. Wirt, J. G., Choy, S., Rooney, P., Hussar, W., Povansnik, S. \& Thompson, H. G. 2005. "The condition of education". Washington, D.C.: National Centre for Education Statistics. 2005.

7. Lage, M. J., Platt, G.J. and Treglia, M. Inverting the classroom: A gateway to creating an inclusive learning environment. The Journal of Economic Education, 31(1):30-43, 2000.

8. Bishop, J. L., and Verleger. M. A. The Flipped Classroom: A survey of the research. 120th ASEE Annual Conference \& Exposition. 23-26, 2013.

9. Kim, M. K., Kim, S. M., Khera, O. Getman, J. The experience of three flipped classrooms in an urban university: an exploration of design principles. Internet and Higher Education, 22, 37-50. 2014.

10. Brame, C. J. (d). Flipping the classroom. Retrieved from The Vanderbilt University Center for teaching website: http://cft.vanderbilt.edu/teaching-guides/teachingactivities/flipping-the-classroom/, 2013.

11. Anderson, H. G., Frazier, L., Anderson, S. L., Stanton, R., Gillette, C., Kim B., Yingling, K. Comparison of Pharmaceutical Calculations Learning Outcomes Achieved Within a Traditional Lecture or Flipped Classroom Andragogy. American Journal of Pharmaceutical Education; 81 (4), 2017.

12. Koo, C. L., Demps, E. L., Farris, C., Bowman, J. D., Panahi, L., Boyle, P. Impact of Flipped Classroom Design on Student Performance and Perceptions in a Pharmacotherapy Course. American Journal of Pharmaceutical Education; 80 (2), 2016.

13. Moravec, M., Williams, A., Aguilar-Roca, N., and O'Dowd, D.K. Learn before lecture; a strategy that improves learning outcomes in a large introductory biology class. CBE-Life Sciences Education, 9(4):473-481, 2010.

14. Kostaris, C., Sergis, S., Sampson, D. G., Giannakos, M. N., and Pelliccione, L., Investing the potential of the flipped classroom model in K-12 ICT Teaching and learning: An Action Research study. Journal of Education Technology \& Society, 20 (1), 261-273, 2017.

15. Simpson, V., Richards, E. Flipping the classroom to teach population health: Increasing the relevance. Nurse Education in Practice 15, 162-167. 2015.

16. Dochy, F., Segers, M., Van den Bossche, P., and Gijbels, D. Effects of problem-based 
learning: A meta-analysis. Learning and instruction, 13(5):533-568, 2003.

17. Gijbels, D., Dochy, F., Segers, M., Van den Bossche, P. Effects of problem-based learning: A meta-analysis from the angle of assessment. Review of educational research, 75(1):27-61, 2005.

18. Burguillo, J.C. Using game theory and Competition-based learning to stimulate student motivation and performance. Computers \& Education, 55, 566-575, 2010. 19. Hamari, J. "Transforming Homo Economicus into Homo Ludens: A Field Experiment on Gamification in a Utilitarian Peer-To-Peer Trading Service", Electronic Commerce Research and Applications, 12(4), 236-245. 2013.

20. Huotari, K. and Hamari, J. "Defining gamification: a service marketing perspective", In Proceedings of the $16^{\text {th }}$ International Academic MindTrek Conference, Tampere, Finland, ACM, pp. 17-22. October 3-5, 2012.

21. Seixas, L. R., Gomes, A. S., Filho, I. J. D. Effectiveness of gamification in the engagement of students. Computers in Human Behaviour, 58, 48-63, 2016.

22. Landers, R. N., Armstrong, M.B. Enhancing instructional outcomes with gamification: An empirical test of the Technology-Enhanced Training Effectiveness Model. Computers in Human Behaviour 71, 499-507, 2017.

23. Dickey, M.D. Game design and learning: a conjectural analysis of how massively multiple online role-playing games (MMORPGs) foster intrinsic motivation. Education Tech Research Dev 55, 253-273, 2007.

24. Sung, H. Y., Hwang, G. J. A collaborative game-based learning approach to improving students' learning performance in science courses. Computers \& Education, 63, 43-51, 2013.

25. Tan, M., and Hew, K. F. Incorporating meaningful gamification in a blended learning research methods class: Examining student learning, engagement. Australasian Journal of Educational Technology · July 2016.

26. Glover, I. Play as you learn: gamification as a technique for motivating learners. In Herrington, Jan, COUROS, Alec and IRVINE, Valerie, (eds.) Proceedings of World Conference on Educational Multimedia, Hypermedia and Telecommunications 2013. Chesapeake, VA, AACE, 1999-2008.

27. Baldeon, J., Puig, A., Rodriguez, I., Lopez, M., Grau, S., Escayola, M., Gamification of elementary math learning: A game designer role-playing experience with kids. II International Workshop on Gamification in Education: gEducation, 2015.

28. Domínguez, A., Saenz-de-Navarrete, J, de-Markus, L., Fernandez-Sanz, L., Pages, C., Martinez-Herraiz, J. J. Gamifying learning experiences: Practical implications and outcomes. Computers \& Education 63:380-392, 2013.

29. Perry, C. Processes of a case study methodology for postgraduate research in marketing. European Journal of Marketing, Vol. 32 No. 9/10, pp. 785-802, (C) MCB University Press, 0309-0566. 1998.

30. Garg, K., Varma, V. A Study of the Effectiveness of Case Study approach in Software Engineering Education. 20th Conference on Software Engineering Education \& Training (CSEET'07) 0-7695-2893-7/07, 2007.

31. Wan, F., and Hannafin, M. J. "Design-based research and technology-Enhanced Learning Environments". ETR\&D, Vol 553, No. 4, pp. 5-23 ISSN 1042-1629. 2005.

32. Popil, I. "Promotion of critical thinking by using case studies as teaching method." Nurse Education Today, 31, 204-207, 2010.

33. Mayo J.A. Using case-based instruction to bridge the gap between theory and practice in psychology of adjustment. Journal of Constructivist Psychology 17, 137-146. 2004.

34. Tiwari, A., Lai, P., So, M., \& Yuen, K. A comparison of the effects of problem-based learning and lecturing on the development of student's critical thinking. Blackwell Publishing 
Ltd 2006. Medical Education; 40, 547-554. 2006.

35. Korkmaz, S. Case-Based and Collaborative-Learning Techniques to Teach Delivery of Sustainable Buildings. Journal of Professional Issues in Engineering Education \& Practice, Vol. 138, No. 2. CASCE, ISSN 1052-3928/2012/2-139-144. April 1, 2012. 36. Yadav, A., Vinh, M., Shaver, G. M., Meckl, P., and Firebaugh, S. Case-Based Instruction: Improving Students' Conceptual Understanding through Cases in a Mechanical Engineering Course. Journal of research in Science Teaching, 51(5), 659-677. 2014. 37. Sankar, C. S., Varma, V., and Raju, P. K. Use of case studies in engineering education: Assessment of changes in cognitive skills. Journal of Professional Issues in Engineering Education and Practice, Vol. 134, No. 3. CASCE, ISSN 1052-3928/2008/3287-296, 2008.

38. Gavin, K. A case study of a project-based learning course in civil engineering design. European Journal of Engineering Education, 36 (6): 547-558. 2011.

39. American Institute of Physics (2000). Marie Curie: Her story in brief. Retrieved from http://www.aip.org/history/curie/brief/ on January 5, 2008.

40. Stewart, Rodney. Investigating the link between self directed learning readiness and project based learning outcomes: the case of international master's Students in an engineering management course. European Journal of Engineering Education, 32(4), 453-465. 2007.

41. Rothwell, W. J., Sensenig, K. J. The sourcebook of self-directed, HDR Press, Amherst, 1999.

42. Boud, D. \& Falchikov, N. Quantitative studies of student self-assessment in higher education: a critical analysis of findings. Higher Education 18, 529-549, 1989.

43. Long, H. B. and Guglielmino, L. M. International Journal of Self-Directed Learning Volume 5, Number 1, spring 2008.

44. Ellis, H. J. C. An Assessment of a Self-Directed Learning Approach in a Graduate Web Application Design and Development Course. IEEE Transactions on Education, 50(1), 2007.

45. Guglielmino, L. M. "Why self-directed learning" in International Journal of selfdirected learning. 5 (1), 2008.

46. Hamid, S., Waycott, J., Kurnia, S., Chang, S. Understanding students' perceptions of the benefits of online social networking use for teaching and learning. Internet and Higher Education 26:1-9. 2015.

47. Silius, K. Students' Motivations for Social Media Enhanced Studying and Learning. Knowledge Management \& E-Learning: An International Journal, 2(1), 51-67. 2010.

48. Baruah, T. D. "Effectiveness of social media as a tool of communication and its potential for technology-enabled connections: A micro level study", International journal of scientific and research publications, 2 (5), 1 ISSN 2250-3153, 2012.

49. Blair, A. Democratising the Learning Process: The Use of Twitter in the Teaching of Politics and International Relations. The Author. Politics @ 2013 Political Studies Association. 2013.

50. Rap, S. and Blonder, R. Thou shall not try to speak in the Facebook language: Students' perspectives regarding using Facebook for chemistry learning. Computers \& Education 114, 69-78. 2017.

51. Chen, Y. C., and Shan, Y. M. The effect of using a Facebook group as a learning management system. Computers in Education Journal. 5(4), 42-53. 2014.

52. Bergmann, J., and Sams, A., The flipped classroom, CSE, 17 (3). 2013/2014.

53. Kostaris, C. et al. Investigating the potential of the Flipped Classroom Model in K-12 ICT Teaching and Learning: An action research study. Educational Technology \& Society, 20 (1), 261-273. 2017.

54. Phillips, C., and Flaherty, J., The use of flipped classrooms in higher education: A 
scoping review. Internet and Higher Education 25, 85-95. 2015.

55. Sung, H. Y., and Hwang, G. J., A collaborative game based learning approach to improving students' learning performance in science courses, Computers \& Education 63, 43-51. 2013.

56. Kayali, S., and Yilmaz, M., An Exploratory Study to assess analytical and Logical Thinking skills of the software practitioners using a Gamification Perspective, Computer \& Education 63, 43-51. 2013.

57. Walsh, S., and Schamroth, S., Gamified vocabulary online resources and enriched language learning, Journal of Adolescent \& Adult Literacy 58(1) September 2014 pg 49-58.

58. Linder, J. C. et al, Student-teachers' conceptions of science, teaching and learning: A case study in preservice science education, International Journal of Science Education, , 12 (4), 381-390. 1990.

59. Henry, M. B., Cooperative learning and case study: does the combination improve students' perception of problem-solving and decision-making skills, Nurse Education Today, 25, 238-246. 2005.

60. Ching C. P., Linking Theory to Practice: A Case-Based Approach in Teacher Education. Procedia - Social and Behavioural Sciences 123, 280 - 288. 2014.

61. Bonney K. M., Case Study Teaching Method Improves Student Performance and Perceptions of Learning Gains, Journal of Microbiology \& Biology Education, p. 21-28. 2015.

62. Birgili, B., Creative and critical thinking skills in Problem-based Learning Environments, Journal of Gifted education and creativity, 2(2), 71-80. 2015.

63. Kreber, C., The relationship between self-directed learning, critical thinking, Studies in Higher Education, 23, 1. 1998.

64. Smith, P. A., Understanding self-regulated learning and its implications for accounting educators and researchers. Issues in Accounting Education, 16 (4), 663-700. 2001. 65. Douglass, C., and Morris, S. R., Student perspectives on self-directed learning, Journal of the Scholarship of Teaching and Learning, Vol. 14, No. 1, 13-25. 2014.

66. Park, S. Y. An Analysis of the Technology Acceptance Model in Understanding University Students' Behavioral Intention to Use e-Learning. Educational Technology \& Society, 12 (3), 150-162. 2009.

67. Mechling, L. C. et al, Using a personal digital assistant to increase independent task completion by students with autism spectrum disorder, Journal of Autism Dev Disord 39, 1420-1434. 2009.

68. Junco R., Heiberger G., Loken E. The effect of Twitter on college student engagement and grades, Journal of Computer Assisted Learning, 27(2), 119-132. 2010.

69. Hunga H. T. and Yuen S. C. Y., Educational use of social networking technology in higher education, Teaching in Higher Education, 15(6), 703-714. 2010.

70. Kivunja C., Do You Want Your Students to Be Job-Ready with 21st Century Skills? Change Pedagogies: A Pedagogical Paradigm Shift from Vygotskyian Social Constructivism to Critical Thinking, Problem Solving and Siemens' Digital Connectivism, International Journal of Higher Education, 3(3), 81-91. 2014.

71. Mao J., Social media for learning: A mixed methods study on high school students' technology affordances and perspectives, Computers in Human Behaviour 33, 213-223. 2014. 